Abstracta Iranica Abstracta Iranica

Revue bibliographique pour le domaine irano-aryen

Volume 28 | 2007

Comptes rendus des publications de 2005

\title{
Birth of the Persian Empire. Vol. I, I.B. Tauris, 147 p., bibliographie, 18 fig. (The Idea of Iran, Vol. 1)
}

\section{Rémy Boucharlat}

\section{(2) OpenEdition}

1 Journals

\section{Édition électronique}

URL : http://journals.openedition.org/abstractairanica/16352

DOI : 10.4000/abstractairanica.16352

ISSN : 1961-960X

Éditeur :

CNRS (UMR 7528 Mondes iraniens et indiens), Éditions de l'IFRI

\section{Édition imprimée}

Date de publication : 15 mai 2007

ISSN : 0240-8910

\section{Référence électronique}

Rémy Boucharlat, «Birth of the Persian Empire. Vol. I, I.B. Tauris, 147 p., bibliographie, 18 fig. (The Idea of Iran, Vol. 1) », Abstracta Iranica [En ligne], Volume 28 | 2007, document 116, mis en ligne le 18 septembre 2007, consulté le 25 septembre 2020. URL : http://journals.openedition.org/ abstractairanica/16352 ; DOI : https://doi.org/10.4000/abstractairanica.16352

Ce document a été généré automatiquement le 25 septembre 2020.

Tous droits réservés 


\title{
Birth of the Persian Empire. Vol. I, I.B. Tauris, 147 p., bibliographie, 18 fig. (The Idea of Iran, Vol. 1)
}

\author{
Rémy Boucharlat
}

1 Le titre est alléchant, le contenu, six conférences données à la SOAS de Londres en 2004, est plus hétérogène, voire dispersé, mais deux autres volumes sont prévus par les éditeurs. Une seule contribution concerne la naissance de l'empire dans le sud-ouest de l'Iran avant Cyrus; les autres abordent la question du lieu et des conditions de naissance de l'Avesta, la question du zoroastrisme des Achéménides et «l'idée de l'Iran" à cette époque; la dernière est un panorama de l'archéologie de l'Iran occidental au Ir mill. av. J.-C.

2 D. Potts, Cyrus the Great and the Kingdom of Anshan (pp. 7-28) retrace le milieu néoélamite dans lequel émerge Cyrus. Ce milieu inclut le Fārs, avec l'ancienne capitale élamite, Malyan. Cyrus est un Anshanite - il se dit roi d'Anshan; par conséquent le coup d'état de Darius serait la revanche de la lignée perse de la famille de Teipses. L'A. va dans le sens de F. Vallat, "Cyrus l'usurpateur », Topoi 1, 1997 (Abs. Ir. 20-21, c.r. $\mathrm{n}^{\circ}$ 174) et article à paraître.

3 F. Grenet, An Archaeologist's Approach to Avestan geography (pp. 29-51) confronte en fait géographie et données des textes en particulier le Vidēvdād. Discutant des différentes hypothèses sur la localisation de Rhaga, Ray pour certains, il déplace ce site très loin à l'est, au Badakhshan. Il conclut que le texte fut rédigé dans le sud de l'Afghanistan, pas plus tard que le milieu du VI ${ }^{\mathrm{e}}$ s. av. J.-C.

4 P. O. Skjærvø, The Achaemenids and the Avesta (pp. 52-84) pose que les Achéménides, et les Iraniens avant eux, sont zoroastriens (de la part de cet auteur, on attendrait mazdéens), en comparant les données littéraires de l'Avesta et les inscriptions perses. Le zoroastrisme du Petit Avesta peut avoir influencé l'ouest depuis l'est dans le cadre de l'empire, et ce nouvel apport correspondrait à l'introduction de Mithra et Anahita dans des inscriptions royales du IV ${ }^{\mathrm{e}} \mathrm{s}$. 
5 A.de Jong, The Contribution of the Magi (pp. 85-99) insiste sur le rôle des mages, dépositaires des textes qu'ils transmettent oralement. Dans sa lutte contre Gaumata le "mage ", Darius se pose en défenseur de la bonne religion. A. Shahbazi, The History of the Idea of Iran (pp. 100-111) soutient « that the idea of Iran as a national entity - that is, a country with linguistic, political and ethnic identity - had originated in the Avesta period and continued an unofficial existence until Ardašīr Pāpakān gave it official sanction [... ]». On ne voit pas où le roi perse présente l'idée de l'Iran comme espace géographique ou entité nationale ; il parle de l'empire, alors que les rois sassanides se diront clairement « roi des rois d'Iran et d'Aniran ».

6 J. Curtis, Iron Age Iran and the Transition to the Achaemenids (pp. 121-131), cherchant les prédécesseurs de l'art achéménide, brosse un tableau très général de l'archéologie depuis Marlik au nord à Nush-i Jan à l'ouest; il conclut «ironically, it is the contributions of the Medes, Persians and Elamites that are most difficult to assess » par rapport aux contributions étrangères, dont mésopotamiennes à l'art perse.

\section{INDEX}

Thèmes : 3.2.2. Pré-Achéménides et Achéménides

\section{AUTEURS}

RÉMY BOUCHARLAT

IFRI / CNRS - Téhéran / Lyon 